\title{
GRADUACIÓN DE ENFERMEROS
}

\section{Palabras del Dr. Luis Carlos Taborda}

\section{Vicerrector Académico}

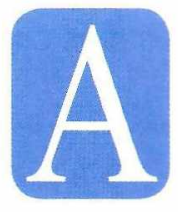

sí las ceremonias de grado se repitan periódicamente en nuestra institución, nunca este acto es el mismo por el especial y único significado personal que tiene para cada uno de ustedes, de sus familiares y de sus amistades. Culmina en este día una de las etapas más significativas de su vida. Al elegir una carrera o una especialidad, el estudiante ha escogido un estilo de vida del cual va a depender de manera principalísima la realización de sus proyectos personales y del sentido del resto de su ciclo de vida y de la manera cómo va a vincularse con la sociedad.

Estos significados, implicaciones, compromisos y condicionantes tienen exigencias, posibilidades y proyecciones aún mayores en el caso de las profesiones de la salud. A lo largo de toda la historia de la humanidad, el profesional de la salud, bajo distintas culturas, paradigmas, miradas y prácticas, ha acompañado al ser humano tan frecuentemente desvalido y desamparado frente al dolor y la enfermedad a lo largo de su ciclo de vida. Como lo han visto ustedes durante su formación, en este momento estamos presenciando grandes transformaciones y prácticas de la medicina y el cuidado general de la salud, que la están proyectando más allá de los tradicionales conceptos sobre la enfermedad. Tal vez, podríamos tipificar así, algunas de tales transformaciones: 1) por un lado todas las maravillosas y promisorias perspectivas sobre la salud, no como lo contrario de la enfermedad, sino como una condición de la calidad de la vida de las personas y un patrimonio, quizá el más importante de los pueblos en el contexto de cada cultura, 2) por otro lado el creciente impacto de las

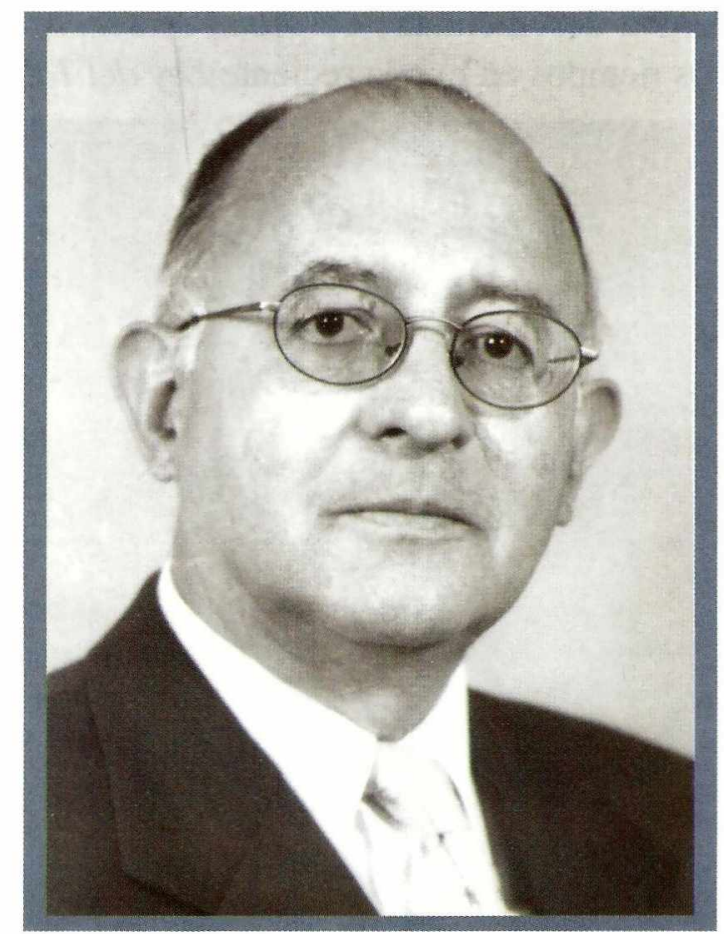

incesantes transformaciones y revoluciones provenientes de las ciencias básicas y sus implicaciones tecnológicas 3) y una mayor conciencia sobre las exigencias bioéticas de la medicina y las ciencias conexas en el marco de un mundo globalizado exigiendo derechos, y en consecuencia, una mayor culturización sobre la calidad del diseño y gestión de los servicios de la salud.

Vale la pena subrayar aquí, que se trata de la calidad total, multidimensional y por supuesto constituida por valores tales como: el respeto, el afecto, la comprensión, la solidaridad y la responsabilidad con el paciente. Asi es el profesional de la salud como educador, orientador, terapeuta y acompañante del paciente, su familia y su entorno, que en el futuro todos esperamos. 
Y regresando a nuestra casa de estudios, quiero señalarles lo siguiente: la misión de una institución educativa y su esperado impacto social, se cumple a través de sus egresados. Nuestra universidad se desenvolverá en el medio social, con el resultado del trabajo, del comportamiento, de la ética y del sentido humano de cada uno de ustedes. Al evaluarlos, nos evalúan a nosotros.

No pueden desvincularse del Alma Mater. Menos en estos tiempos en que la reciente Ley del Talento
Humano les va a exigir mantenerse en estudio permanente, para lograr la periódica recertificación profesional. No podrán afrontar tales exigencias si se mantienen al margen de las comunidades académicas. Nuestra universidad estará siempre dispuesta a ofrecerles permanentemente lo mejor en el plano de los conocimientos y los valores para tales propósitos.

Reciban de nuestra parte las felicitaciones más cordiales para ustedes y sus familiares.

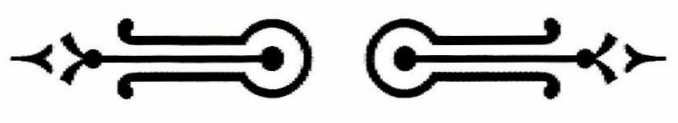

